\title{
CALCULATION OF STAGES OF FINITE VERBS MODULATION IN THE RUSSIAN LANGUAGE ${ }^{1}$
}

\author{
Victor V. Shigurov \\ National Research Ogarev Mordovia State University, Saransk, Russia
}

\begin{abstract}
The problem of stepwise transposition of verbs into the category of parenthetical-modal units is considered in the paper. The research relevance is stipulated by insufficient knowledge of stepwise mechanisms of words and word forms transposition into other parts of speech and categories. The main purpose of the research is to calculate the stages and the limit of modulation for different groups of verbal units. General scientific, general linguistic and special methods (comparison, generalization; descriptive method, opposition, distribution and transformation analysis; linguistic experiment) were used as tools. The study of verb modulation stages has enables revealing the dynamics of corresponding fragments of the language system; use in the process of linguistic evolution of different ways of enhancing part of speech models, primarily due to their own, internal resources - "splitting" words and formation of new language units on the basis of a complex or individual word forms by means of interjectivation, partitioning, conjunctionalization, modulation, etc. It is established that the verbs belonging to different lexical groups are exposed to unequal modulation degree; finite verbs go through two to five stages of transposition until they are included into the category of parenthetical-modal units. The facts of a purely functional modulation of word forms occurring within the source verb lexemes, as well as their functionaland-semantic transposition into modal utterance components associated with the formation of lexical-and-grammatical homonyms are revealed. The results of the work can be used to create a transpositional grammar of the Russian language.

Key words: Russian language, grammar, transposition, verb, parenthetical-modal word, modulation stage.

Citation. Shigurov V.V. Calculation of Stages of Finite Verbs Modulation in the Russian Language. Vestnik Volgogradskogo gosudarstvennogo universiteta. Seriya 2. Yazykoznanie [Science Journal of Volgograd State University. Linguistics], 2020, vol. 19, no. 2, pp. 20-30. (in Russian). DOI: https://doi.org/10.15688/jvolsu2.2020.2.2
\end{abstract}

\section{ИСЧИСЛЕНИЕ СТУПЕНЕЙ МОДАЛЯЦИИ ФИНИТНЫХ ГЛАГОЛОВ В РУССКОМ ЯЗЫКЕ ${ }^{1}$}

\author{
Виктор Васильевич Шигуров \\ Национальный исследовательский Мордовский государственный университет им. Н.П. Огарева, \\ г. Саранск, Россия
}

\begin{abstract}
Аннотация. В статье рассмотрена проблема ступенчатой транспозиции глаголов в разряд вводно-модальных единиц. Актуальность работы обусловлена недостаточной изученностью механизма ступенчатой транспозиции слов и словоформ в области частей речи и межчастеречных разрядов. Цель работы - исчисление этапов и предела модаляции для разных групп глагольной лексики. В качестве инструментария использованы общенаучные, общелингвистические и специальные методы (сравнение, обобщение; описательный метод, оппозиционный, дистрибутивный и трансформационный анализ; лингвистический эксперимент). Исследование ступеней модаляции глаголов показало динамику фрагментов языковой системы; реализацию в процессе языковой эволюции разных способов обогащения частей речи - прежде всего за счет собствен\%ै ных, внутренних ресурсов: «расщепления» слов и образования на базе комплекса или отдельных словоформ исходных лексем новых языковых единиц при интеръективации, партикуляции, конъюнкционализации, модаляции и т. п. Установлено, что степень модаляции у глаголов разных лексических групп неодинакова; количество ступеней транспозиции финитных глаголов в разряд вводно-модальных единиц варьируется от двух до
\end{abstract}


пяти. Выявлены факты функциональной модаляции словоформ, протекающей в пределах исходных глагольных лексем, а также их функционально-семантической транспозиции в модальные компоненты высказывания, сопряженные с образованием лексико-грамматических омонимов. Результаты работы могут быть использованы при создании транспозиционной грамматики русского языка.

Ключевые слова: русский язык, грамматика, транспозиция, глагол, вводно-модальное слово, ступень модаляции.

Цитирование. Шигуров В. В. Исчисление ступеней модаляции финитных глаголов в русском языке // Вестник Волгоградского государственного университета. Серия 2, Языкознание. - 2020. - Т. 19, № 2. - С. 20 30. - DOI: https://doi.org/10.15688/jvolsu2.2020.2.2

\section{Введение}

В русской речи широкое употребление получили слова и выражения, позволяющие компактно, но семантически емко передавать мысли и чувства человека. Потребность в такой экономии удовлетворяется во многом благодаря механизму транспозиции, действующему на разных уровнях языковой системы и способствующему обогащению смысловых структур языковых единиц. Так, действием закона экономии языковых средств и речевых усилий обусловлена, в частности, транспозиция качественных наречий типа страшно, ужасно в количественные в словосочетаниях страшно красивый, ужасно страшный: «Совмещение в одной языковой единице нескольких значений позволяет в более компактной форме передать большее количество информации» [Воротников, 2003, с. 82]. Появление многих синкретичных речевых фактов связано с разными типами транспозиции слов и словоформ в системе частей речи и межчастеречных разрядов (а также грамматических категорий и лексико-грамматических разрядов). По этой причине актуальным и значимым для теории грамматики представляется комплексное исследование устройства и принципов работы механизма частеречной транспозиции, который порождает в речи разные типы и звенья (ступени) категориальной трансформации лингвистических единиц, концентрируя «сгустки» человеческой мысли - синкретичные структуры с набором дифференциальных свойств нескольких классов слов; ср., например, свойства глаголов, союзов, предикативов и вводно-модальных единиц, выраженные инфинитивом видать: К нему не просто попасть. Видать, мастер он отменный. А.М. Пешковский писал: «Как человек может быть одновременно и умным, и блондином, так и слово может быть одновременно и прилагательным, и местоимением (“такой”), и глаголом, и числительным (“утраиваю”), и прилагательным, и предметным словом (“каменный”), и существительным, и качественным словом (“белизна”) и т. д.» [Пешковский, 1923, с. 47-48].

Теоретической основой исследования синкретизма в грамматическом строе русского языка является признание того, что части речи отражают концептуальную картину мира, все элементы которой диалектически взаимосвязаны и взаимообусловлены. В силу сказанного адекватным можно признать представление системы частей речи, вскрывающее механизм их взаимодействия, взаимопроникновения. Это проявляется в комбинаторике и удельном весе разных категориальных признаков в структуре словоформ, включенных в один или несколько транспозиционных процессов.

Актуальность обсуждаемой проблемы состоит в том, что изучение типов ступенчатой транспозиции языковых единиц в области частей речи и межчастеречных разрядов, грамматических категорий и лексико-грамматических разрядов (а также в сфере синтаксических единиц - синтаксем, словосочетаний, предложений и т. д.) позволяет обнаружить «скрытые» тенденции, динамику фрагментов языковой системы; реализацию в процессе языковой эволюции разных способов обогащения частей речи - прежде всего за счет собственных, внутренних ресурсов: «расщепления» (раздвоения, растроения и т. д.) слов и образование на базе комплекса или отдельных словоформ исходных лексем новых языковых единиц при функциональной и функционально-семантической интеръективации, прономинализации, предикативации, модаляции, адвербиализации и т. п. В недостаточной мере изучены в русской грамматике многие типы синкретичных (периферийных и гибрид- 


\section{РАЗВИТИЕ И ФУНКЦИОНИРОВАНИЕ РУССКОГО ЯЗЫКА}

ных) структур, находящихся в переходных зонах между разными классами слов, на пересечении нескольких транспозиционных процессов (о разных типах транспозиции см.: [Балли, 1955; Ким, 1978; Курилович, 2000; Теньер, 1988; Мигирин, 1971; Marchand, 1967]).

\section{Материал и методы исследования}

Объектом исследования в настоящей статье является транспозиционный процесс модаляции русских глаголов, который может быть осмыслен двояко на синхронном срезе языка - в динамическом и статическом аспектах. Обоснование возможности двоякой трактовки синхронного словообразования дается в исследовании Е.С. Кубряковой (см.: [Кубрякова, 1981]).

Динамический аспект заключается в анализе процесса вводно-модальной транспозиции глагольных словоформ, ступеней их «движения» в типовых контекстах к вводно-модальным компонентам высказывания (шкала переходности) [Г(лаг) $\rightarrow$ Г(лаг) м(од) $\rightarrow$ г(лаг) $\mathbf{м}($ дд) $\rightarrow$ г(лаг) $\mathbf{M ( о д ) ~} \rightarrow$ М(од)]. Статический аспект модаляции заключается в комплексном исследовании его результатов, то есть периферийных глаголов [Г(лаг) м(од)], периферийных [г(лаг) М(од)] и ядерных [М(од)] вводно-модальных слов и выражений, а также гибридных, глагольно-междометных структур [г(лаг) м(од)] (об оппозиционном методе изучения фактов переходности и синкретизма в грамматическом строе языка см., например: [Бабайцева, 2000; Баудер, 1982; Калечиц, 1990; Шигуров, 1993; 2007; 2009; 2015; 2016]).

Следствием ступенчатой функциональной и функционально-семантической транспозиции языковых единиц из глаголов в разряд вводно-модальных единиц является изменение дифференциальных признаков в структуре словоформ на разных стадиях модаляции. Речь идет об их десемантизации и декатегоризации, то есть ослаблении и/или утрате семантико-грамматических свойств глагола и соответственно приобретении признаков вводно-модальных компонентов высказывания (см., например: [Шигуров, Шигурова, 2019]).

Поскольку степень модаляции разных групп глагольной лексики неодинакова, целью работы ставится исчисление основных этапов модаляции и предела их категориальной трансформации. При этом за основу берется вышеуказанная шкала переходности.

В качестве инструментария в исследовании применялись общенаучные, общелингвистические и специальные методы (сравнение, обобщение; описательный метод, оппозиционный, дистрибутивный и трансформационный анализ; лингвистический эксперимент). Примеры употребления исследуемых единиц извлечены из Национального корпуса русского языка (при цитировании источников отсылка к нему опускается).

\section{Результаты и обсуждение}

Исследование показывает, что количество ступеней модаляции финитных глаголов варьируется от двух до пяти.

1. Г(лаг) $\rightarrow$ Г(лаг) м(од).

2. Г(лаг) $\rightarrow$ М(од).

3. Г(лаг) $\rightarrow$ Г(лаг) м(од) $\rightarrow$ г(лаг) м(од).

4. Г(лаг) $\rightarrow$ Г(лаг) м(од) $\rightarrow$ г(лаг) $\mathbf{м}($ од) $\rightarrow$ г(лаг) М(од).

5. Г(лаг) $\rightarrow$ Г(лаг) м(од) $\rightarrow$ г(лаг) $\mathbf{м}($ од) $\rightarrow$ г(лаг) М(од) $\rightarrow$ М(од).

Заметим, что распределение речевых фактов по звеньям шкалы модаляции в настоящей работе несколько отличается от того, что представлено в грамматических описаниях А.Я. Баудера [1982], В.В. Бабайцевой [2000], И.В. Высоцкой [2006].

Первый тип двухступенчатой транспозиции образуют финитные формы глаголов, представляющие при модаляции ступени Г(лаг) $\rightarrow$ Г(лаг) м(од). К ступени Г(лаг) относятся ядерные глагольные словоформы, обладающие полным набором основных семантико-грамматических характеристик глагола, а к ступени Г(лаг) м(од) - соотносительные с ними периферийные глагольные словоформы в функции предиката главной части сложноподчиненного предложения с придаточным изъяснительным. Модус и диктум в конструкциях с периферийными глаголами синтаксически разделены: модальную оценку ситуации эксплицирует глагольный предикат главной части сложноподчиненного предложения, а само оцениваемое положение дел - изъяснительная придаточная часть. Ступень Г(лаг) м(од) для рассматриваемых 
глагольных лексем является пределом их модаляции.

Ср. контексты употребления словоформы слушаю, представляющей на шкале модаляции зоны ядра (1) и периферии глагола (2), и словоформы чувствую, достигающей при модаляции зоны периферии вводно-модальных единиц (3):

(1) «Я слушаю приказания прокуратора», сказал пришедший, подходя к столу (М. Булгаков. Мастер и Маргарита);

(2) Слушаю по радио, как шеф открывает сессию, и торжественные речи разных уважаемых особ (В. Аксенов. Звездный билет);

(3) Щелкнуло там что-то и, чув ствую, стало все на место (Ю. Домбровский. Факультет ненужных вещей).

Второй тип двухступенчатой модаляции Г(лаг) $\rightarrow$ М(од) представляют финитные формы глаголов, манифестирующие на шкале переходности исходный и конечный пункты межкатегориальной транспозиции, а точнее, ядерные зоны глаголов и вводно-модальных единиц. Ср. контексты собственно глагольного (4)-(8) и вводно-модального употребления императивов кажись, пожалуй, а также редуцированной императивной словоформы поди (из пойди) (9)-(11):

(4) Ты не большевик - кажись им, ты не патриот - кажись им! (А. Алдан-Семенов. Красные и белые);

(5) Милый мой, в костюме старом На глаза мне не кажись: Ведь построили недаром Мы зажиточную жизнь (Н. Колпакова. Терский берег);

(6) Неужто таки и грешные-то мои молитвы не доходили! (К Софье.) Письмецо-то мне пожалуй. (Почти вырывает.) Я об заклад бьюсь, что оно какое-нибудь амурное (Д. Фонвизин. Недоросль);

(7) А ты, Кутейкин, пожалуй-ка сюда завтре да потрудись расчесться с самой госпожою (Д. Фонвизин. Недоросль);

(8) Я протягивала руки: «Валюнчик, поди к маме!» (И. Грекова. Перелом);

(9) Вся живая природа, кажись, понимала серьезность пришедших перемен (В. Аксенов. Новый сладостный стиль);

(10) Пожалуй, это единственное чтение, которое не огорчает меня (Л. Улицкая. Казус Кукоцкого);

(11) Поди, на эту самую корейскую войну идет такая прорва народных денег, что это непостижимо человеческому уму! (В. Пьецух. Шкаф).
Третий тип составляют глаголы, проходящие три этапа в процессе модаляции: $\Gamma($ лаг $) \rightarrow$ Г(лаг) м(од) $\rightarrow$ г(лаг) м(од). Это, в частности, такие глаголы восприятия, как ощущзаю, достигающие ступени гибридных, глагольно-модальных образований в бессоюзных сложных предложениях с пояснительными отношениями между предикативными частями.

Ср. типовые контексты употребления словоформы ощущзаю, эксплицирующие зоны глагольного ядра (12) и периферии (13), а также область гибридных образований (14):

(12) Пишу эти строки и явственно ощущаю на шее колючий башлык (С. Голицын. Записки уцелевшего);

(13) Ощущаю, как на голове начинают шевелиться волосы от чувства, которое, пожалуй, сродни священному ужасу (С. Хведченя. Исторический розыск. Страсти по Илье);

(14) Кончилась моя болезнь. Ощущаю: кончилась (М. Вишневецкая. Вышел месяц из тумана).

Четвертый тип представлен четырехступенчатой моделью транспозиции глаголов в разряд вводно-модальных единиц. Типовые контексты отражают следующие звенья шкалы переходности: Г(лаг) (зона ядерных глаголов) $\rightarrow$ Г(лаг) м(од) (зона периферийных глаголов) $\rightarrow$ г(лаг) м(од) (зона промежуточных, глагольно-модальных структур) $\rightarrow$ г(лаг) М(од) (зона периферийных вводно-модальных единиц). При этом семантическое развитие каждого из глаголов, вовлеченных в ступенчатый процесс функциональной модаляции, протекает в рамках единого слова, то есть при сохранении тождества глагольной лексемы. Данную модель межкатегориальной транспозиции языковых единиц можно проиллюстрировать на примере разных грамматических форм лица и числа финитных глаголов: форм 1-го л. ед. ч. глаголов типа знаю, вижу, замечу, признаюсь; форм 1-го л. мн. ч. глаголов типа допустим, заметим, предположим; форм 2-го л. ед. ч. глаголов типа понимаешь, пойми, представляешь, предcmaвb; форм 2-го л. мн. ч. глаголов типа знаете, посудите, заметьте; форм 3-го л. ед. ч. глаголов типа случается, оказывается, бывает; форм 3-го л. мн. ч. глаголов типа говорят, сообщают. Ср. типовые контексты 


\section{РАЗВИТИЕ И ФУНКЦИОНИРОВАНИЕ РУССКОГО ЯЗЫКА}

употребления указанных глагольных форм, которым соответствуют разные ступени их модаляции на шкале переходности.

Контексты употребления ядерных глаголов [ступень Г(лаг)]:

(15) Я человек большого, горького опыта. Знаю жизнь! (М. Булгаков. Театральный роман);

(16) Допустим такой случай: вылепивши из глины человека, Творец позабыл бы вдохнуть в него жизнь - получилась бы глиняная фигура со всеми атрибутами и потенциями человека, но не человек (Л. Андреев. Москва. Мелочи жизни);

(17) Как ты себе представляешь вашу совместную жизнь? (А. Маринина. Ангелы на льду не выживают);

(18) ...Но вы хоть по старой дружбе поймите обстоятельства, жалованье, семейство (М. Шишкин. Всех ожидает одна ночь);

(19) В Америке успех бывает самый разный. Например, коммерческий успех, далеко не всегда сопровождающийся известностью (С. Довлатов. Переводные картинки);

(20) Вечером, в тихий час, все снова говорят о радистке (В. Гроссман. Жизнь и судьба).

Контексты употребления периферийных глаголов [ступень Г(лаг) м(од)]:

(21) Знаю, что это не секретарша, а горе мое, обуза, и все-таки держу (И. Грекова. Дамский мастер);

(22) Допустим, что вам удастся инсценировать мою гибель (А. Беляев. Продавец воздуха);

(23) Представляешь, что мы там у них натворили? (С. Сергеев-Ценский. Лаванда);

(24) Поймите, что язык может скрыть истину, а глаза - никогда! (М. Булгаков. Мастер и Маргарита);

(25) Бывает, что человек пытается сам решить какую-то проблему, хотя она решена уже тысячи лет назад (В. Пелевин. Желтая стрела);

(26) Говорят, что у каждого человека в жизни должна быть цель (А. Алексин. Раздел имущества).

Контексты употребления гибридных, глагольно-междометных образований [ступень г(лаг) м(од) с подступенями г(лаг) м(од) 1 и Г(лаг) м(од) 2]:

Подступень г(лаг) м(од) 1:

(27) Тут ведь - жалоба на тебя. Знаю: вздор! А отъехать тебе надобно (Б. Евсеев. Евстигней);

(28) Будет именной указатель. Допустим: Алексеев, стыковщик. Кульгугин, подрывник (К. Метелица, К. Немоляев. Самая новенькая история СССР);
(29) Представляешь: пронес ты его в класс на контрольную, шепнул вопрос, а он подскажет так громко, что мертвяки и те сбегутся... (Д. Емец. Таня Гроттер и магический контрабас);

(30) Поймите: никто не станет покупать вашу квартиру за двадцать две тысячи, чтобы через месяц продать ее опять за двадцать две (А. Волос. Недвижимость);

(31) Бывает так: работа идет по графику, все что-то делают, отснятый материал увеличивается, но властвует над всеми какое-то мелочное раздражение, кто-то на кого-то льет грязь, кто-то замкнулся и ушел в себя, кто-то сцепился с кем-то по пустякам, и тогда это уже не работа и материал, это брак (В. Аксенов. Пора, мой друг, пора);

(32) Но бывает - и музыка не в радость (Б. Евсеев. Евстигней);

(33) Говорят: не подпишешь, что виноват, сегодня же твоя жена будет сидеть рядом (Ю. Домбровский. Факультет ненужных вещей);

(34) Вот говорят: не учи ученого. А я тебя, такого ученого, могу даже запросто научить (Л. Зорин. Глас народа).

\section{Подступень г(лаг) м(од) 2:}

(35) Я знаю, вы не такой, как другие, - я вам верю (А. Аверченко. Ниночка);

(36) Допустим, раскопаешь ты все подробности, а дальше? (А. Слаповский. Большая Книга Перемен);

(37) Представляешь, в вагоне только три купе, и в каждом отдельная ванна (В. Пелевин. Желтая стрела);

(38) Поймите, у меня есть совесть, мне больно, мне тяжело, да не обязан я, почему я должен подписывать, я так измучен, дайте мне право на спокойную совесть (В. Гроссман. Жизнь и судьба);

(39) Бывает, первоклассник уже бойко читает, а в тетради такие каракули - просто беда! (И. Ковалева. В карте запись);

(40) Говорят, в автобусах должно быть написано над дверями: «Выход с другой стороны» (А. Волос. Недвижимость).

Контексты употребления периферийных отглагольных вводно-модальных слов и выражений [ступень г(лаг) М(од)]:

(41) Испей, ништо... - Ты, знаю, хрещена, чего брезгать! - Я старой веры (А. Чапыгин. Разин Степан);

(42) Мне ничего, а им, знаю, лестно, что у них статская советница... (А. Потехин. Новейший оракул);

(43) Какой-нибудь московский автор, допустим, пишет: «Евгений Федорович Терентьев, дород- 
ный мужчина лет шестидесяти четырех, проснулся среди ночи от грохота землечерпалки» (С. Довлатов. Переводные картинки);

(44) А мне, представляешь, приснилось, что ты писатель и сидишь на моей шее $(\mathrm{O}$. Зайончковский. Счастье возможно: роман нашего времени);

(45) Я совсем другая, обыкновенная, поймите, вы все обо мне придумали... (О. Павлов. Асистолия);

(46) С курорта и то, бывает, приезжают прозрачные (В. Шукшин. Калина красная);

(47) Холсты, говорят, разгорались плохо, и особенно не разгорался натюрморт с чайником (Ю. Коваль. Чайник).

Зона периферии вводно-модальных единиц является пределом модаляции для финитных глаголов рассматриваемого типа. У каждой такой словоформы, как бывает, говорят, в русском языке собственно-глагольное и вводно-модальное употребление эксплицируют соответственно исходный и конечный пункты модаляции, то есть грамматические омонимы бывает, говорят и т. п. (глаголы в предикативной функции) и бывает, говорят (отглагольные модаляты в вводно-модальной функции). Важно подчеркнуть, что при модаляции указанных глаголов новых лексем не образуется: в каждом случае вводно-модального употребления такой словоформы не наблюдается ее смыслового отхода от исходной глагольной лексемы (бывать, говорить). Распределение модусной и диктумной семантики в типовых контекстах, представляющих разные стадии модаляции глаголов, неоднотипно. На ступени ядра глаголов диктум и модус сосредоточены в рамках одной предикативной единицы с модусно окрашенным предикатом, в то время как остальные ступени модаляции демонстрируют синтаксическое разделение модуса и диктума: оценка говорящим того или иного фрагмента высказывания (модус) осуществляется в первой части сложноподчиненного или бессоюзного предложения (зона периферии глаголов и зона гибридных структур) или в обособленном вводно-модальном обороте простого предложения (зона периферии вводно-модальных единиц), а оцениваемое субъектом модуса положение дел - в остальной части высказывания.

К пятому типу модаляции могут быть отнесены те немногочисленные глагольные словоформы, которые проходят в своем дви- жении к вводно-модальным словам и выражениям все пять этапов, что соответствует пяти звеньям шкалы переходности.

Последний этап (зона ядерных вводномодальных единиц глагольного происхождения) сопряжен с выходом глагольных словоформ за пределы исходных глагольных лексем и образованием не только грамматических, но и лексических омонимов. Такой функционально-семантический тип модаляции имеет место, как представляется, в двух случаях вводно-модального употребления финитных глаголов.

Во-первых, это происходит в случае полной десемантизации глагольного слова, что встречается, в частности, при использовании глагольной словоформы видищь исключительно в контактоустанавливающей функции с утратой значения зрительного восприятия предмета. Видишь выступает здесь в качестве пустой вставки, служащей для привлечения внимания адресата к сообщаемому; ср.: ядерный глагол со значением зрительного восприятия предмета (48) и отглагольные ядерные модаляты в функции привлечения внимания собеседника к предмету речи (49):

(48) Плывешь в гондоле и видишь дворцы дожей, дом, где жила Дездемона... (А. Кушнер. Почему они не любили Чехова?);

(49) Видишь ли, я не встречала пассажирок в поезде и даунов, которым можно рассказывать очень личное (С. Носов. Фигурные скобки).

Словоформа видишь в целом может демонстрировать разные этапы транспозиции глагола в вводно-модальные слова и выражения; ср. экспликацию ступеней ее модаляции в типовых контекстах.

Ступень Г(лаг) шкалы модаляции (ядерная форма глагола):

(50) Видишь эти маленькие белые узелочки между косточками моих пальцев? (В. Катаев. Алмазный мой венец).

Ступень Г(лаг) м(од) шкалы модаляции (периферийная форма глагола):

(51) Видишь, что старшего товарища заносит, и сидишь, как воды в рот набрал (А. Маринина. Последний рассвет). 
Ступень г(лаг) м(од) шкалы модаляции (гибридные, глагольно-модальные образования):

(52) Вон видишь: на березе осталось двенадцать листиков (С. Козлов. Правда, мы будем всегда?);

(53) Видишь, я сделал все дела и уже вернулся (В. Маканин. Отдушина).

Ступень г(лаг) М(од) шкалы модаляции (периферийный отглагольный модалят):

(54) Давай рассказывай. Яж, видишь, пишу! Пиши, пиши, раз все уплыло из рук, тогда, значит, ты пиши (Ю. Домбровский. Факультет ненужных вещей).

Ступень М(од) шкалы модаляции (ядерный отглагольный модалят):

(55) Есть, видишь ли, люди, которым очень не нравится город... (В. Шукшин. Печки-лавочки).

Во-вторых, модаляции функциональносемантического типа, на наш взгляд, подвержены финитные глаголы, совмещающие модаляцию с другими типами транспозиции, причем такими, которые обусловливают их выход из состава полнознаменательной лексики в служебные слова (союзы, частицы) и междометия. Речь идет о комбинаторике транспозиционных процессов следующего типа:

Модаляция + конъюнкционализация (функциональное сближение с союзами); ср.:

(56) Кажется, у меня опять выходит что-то не то (В. Белоусова. Второй выстрел);

(57)Выходит, у Ростислава, молодого, неопытного, впору мне, многоопытной, учиться? Выходит, так (И. Грекова. Перелом).

Модаляция + партикуляция (функциональное сближение с частицами); ср.:

(58) Под этим разумеется способность вмиг схватить положение неприятеля и моментально воспользоваться его положением в свою пользу (П. Ковалевский. Генералиссимус Суворов);

(59) - Говорить не о чем, - согласился я. - Разумеется, вы не откажетесь (А. Волос. Недвижимость).

Модаляция + интеръективация (функциональное сближение с междометиями); ср.:

(60) Кажется «уже да», а подумаешь - «еще нет»... (И. Грекова. Фазан);
(61) «Смотри, какой он устроил костер». - «Подумаешь, костер!» (В. Губарев. Трое на острове);

(62) «Извините за мой внешний вид, - сказал Гриша, широко улыбаясь разбитым ртом и косясь на свой изуродованный лацкан, - так обстоятельства сложились» (В. Пелевин. Желтая стрела);

(63) С «условной» франшизой - по-другому. Тут уж, извините, как условитесь. Кроме всего прочего, понятие и размер франшизы различаются по типовому признаку (Д. Литошик. Автомобиль напрокат).

В приведенных примерах можно наблюдать бо́льшую (при интеръективации) или меньшую (при партикуляции и конъюнкционализации) степень семантического отхода подвергающихся категориальным преобразованиям словоформ от исходных глагольных лексем, а в ряде случаев, по-видимому, и образование на их основе новых слов - лексических омонимов, которые, однако, в соответствии с лексикографической традицией даются в толковых словарях русского языка в пределах одной словарной статьи на глагол. Если при функциональной модаляции, как известно, мы имеем дело с полисемией, формированием нового, вводно-модального значения у той или иной словоформы в рамках глагольной лексемы (ср., например, общность сем в значениях словоформ разумеется, выходит при собственно глагольном и вводно-модальном употреблении), то в случае функционально-семантической модаляции - с лексической омонимией, резким семантическим отходом словоформы, например видишь (ли) от глагола (отсутствие общих сем в ее глагольном и вводно-модальном значениях). Применительно к упомянутым выше словоформам типа под $u$, кажись в субъективно-модальном значении предположения можно говорить о лексикализации форм глагольного императива.

Особого упоминания заслуживает функциональный тип модаляции глагольных словоформ типа говорит, сопряженный с их редукцией на последнем этапе транспозиции (грит, гыm). В целом же словоформа говорит может представлять разные стадии модаляции: ядро глагола [Г(лаг)] (64), его периферию [Г(лаг) м(од)] (65), сферу гибридных, глагольно-модальных образований [г(лаг) м(од)] (66) и зону периферии отглагольных вводно-модальных единиц [г(лаг) М(од)] (67); ср. экс- 
пликацию указанных ступеней модаляции в типовых контекстах:

(64) Группа поэтов в углу говорит о Данте (В. Аксенов. Новый сладостный стиль);

(65) Мама говорит, что Айша была любимицей в их огромной семье, где одних детей - братьев и сестер - было человек десять (Ф. Искандер. Слово);

(66) Ничего она толком не знает. Говорит: уехала куда-то к морю... (В. Белоусова. Второй выстрел);

(67) Выручил меня толстяк с блокнотом. Давайте, говорит, я спою... - «Только не здесь, - попросил я, - в автобусе» (С. Довлатов. Заповедник).

Вводно-модальное слово грит (2ыm) сформировалось в устной речи как сокращенный вариант формы 3-го л. ед. ч. глагола говорит. Например:

(68) Говорит это, а сам смеется. Хорошо. Ну, он и рассказывает: приехали, грит, в «Дрезден» два господина, не то, чтобы настоящие господа, да и к купцу нельзя применить. Заняли, грит, лучший номер и сейчас спать; целые сутки спали. Мы уж, грит, хотели полиции объявлять, ну, а они в этот раз и проснись. Потребовали самовар, водки и закуски. Фициант подает им все в порядке, как следует порядочным господам, а они его на смех подняли (Д. Мамин-Сибиряк. Клад).

Образование периферийного вводно-модального слова грит было вызвано функциональной модаляцией глагола. Поэтому говорить о появлении лексических омонимов в этом случае не приходится, да и о грамматической омонимии типа говорит (глагол в личной форме) и грит (периферийное отглагольное вводно-модальное слово) при фонетическом расхождении сопоставляемых словоформ - только с большой степенью условности. Нечто схожее наблюдается при образовании императивных междометий на базе усеченных глагольных словоформ типа $B 3 b l$ ! $Y_{c b}$ !, представляющих команды для натравливания собак; а также Товсь! Пли!, используемых в воинской среде в качестве приказов, побуждающих подчиненных изготовиться к стрельбе и открыть огонь на поражение; ср.: Огонь! Интересна история возникновения междометия усь на базе исчезнувшего из языка глагола * кусити в форме повелительного наклонения *куси со значением 'кусай'; в результате сокращения возникли междометия кусb, $y c b$.
Грамматическую омонимию типа готовься (глагол в форме императива) и товсь (периферийное отглагольное междометие) можно усматривать здесь также весьма условно (подробнее об этом см.: [Шигуров, 2009]).

Следует добавить, что в сфере модаляции глаголов, в отличие от кратких прилагательных и предикативов, не встречается такое явление, как энантиосемия, то есть развитие в смысловой структуре языковых единиц антонимических значений. Ср., например, функционально-семантическую транспозицию адъективной словоформы видно в разряд вводно-модальных единиц: По всем приметам видно, что весна будет ранняя (₹ 'бесспорно') $\rightarrow$ Весна, видно, будет ранняя ( ‘по-видимому') (пример составлен автором статьи. - B. W.) (о ступенчатом характере модаляции видно см.: [Бабайцева, 2000]).

Ядерный модалят (по всем приметам видно), как и периферийный модалят (видно), определяет позицию субъекта модуса, оценивающего сообщаемое с точки зрения достоверности информации. Отличие заключается в том, что ядерное вводно-модальное слово эксплицирует семантику не категорической, а проблематической достоверности, то есть значение сомнения, предположения. Это сближает его с синонимическим рядом таких единиц, как по-видимому, наверное, очевидно. Важно то, что формирование антонимического значения на основе энантиосемии вызывает нарушение семантического тождества исходного адъективного слова (видно) и развитие лексико-грамматического омонима. Для сравнения отметим функционально-семантическую предикативацию существительных типа охота, досуг, в результате которой также формируются лексические и грамматические омонимы, например охота (существительное) - охота (отсубстантивный предикатив, развивший на базе энантиосемии антонимическое модальное значение 'неохота'). Ср.: Больно охота работать! ( $\approx$ 'неохота') (пример составлен автором статьи. $-B$. $W$.).

\section{Заключение}

Исследование механизма транспозиции языковых единиц из глагольного класса в межчастеречный семантико-синтаксический раз- 


\section{РАЗВИТИЕ И ФУНКЦИОНИРОВАНИЕ РУССКОГО ЯЗЫКА}

ряд вводно-модальных компонентов высказывания показывает, что степень модаляции у глаголов разных лексических групп неодинакова, в связи с чем можно выделять несколько типов финитных глаголов, различающихся количеством ступеней их транспозиции в вводно-модальные слова и выражения. Количество этапов модаляции финитных глаголов варьируется от двух до пяти (включительно), что связано, с одной стороны, с функциональным и функционально-семантическим характером данного типа транспозиции, а с другой - с пересечением в структуре категориально перерождающихся словоформ сразу нескольких транспозиционных процессов - модаляции, партикуляции, конъюнкционализации и интеръективации.

\section{ПРИМЕЧАНИЕ}

${ }^{1}$ Исследование выполнено при финансовой поддержке РФФИ в рамках научного проекта № 19-012-00013 «Изменения языковых единиц на разных стадиях модаляции в синхронном освещении: междисциплинарный подход и методика индексации».

The reported study was funded by RFBR in the framework of research project no. 19-012-00013 "Changes in Linguistic Units at Different Stages of Modalation in Synchronous Lighting: An Interdisciplinary Approach and the Methodology of Indexing”.

\section{СПИСОК ЛИТЕРАТУРЫ}

Бабайцева В. В., 2000. Явления переходности в грамматике русского языка. М. : Дрофа. $640 \mathrm{c}$.

Балли Ш., 1955. Общая лингвистика и вопросы французского языка. М. : Изд-во иностр. лит. 416 с.

Баудер А. Я., 1982. Части речи - структурно-семантические классы слов в современном русском языке. Таллин : Валгус. 184 с.

Воротников Ю. Л., 2003. Слово и время. М. : Наука. $167 \mathrm{c}$.

Высоцкая И. В., 2006. Синкретизм в системе частей речи современного русского языка. М. : Изд-во МПГУ. 304 с

Калечиц Е. П., 1990. Взаимодействие слов в системе частей речи: межкатегориальные связи. Свердловск : Изд-во Урал. ун-та. 160 с.

Ким О. М., 1978. Транспозиция на уровне частей речи и явление омонимии в современном русском языке. Ташкент : Фан. 228 с.
Кубрякова Е. С., 1981. Типы языковых значений. Семантика производного слова. М. : Наука. $200 \mathrm{c}$

Курилович Е., 2000. Очерки по лингвистике. Биробиджан : ТРИВИУМ. 50 с.

Мигирин В. Н., 1971. Очерки по теории процессов переходности. Бельцы : [б. и.]. 199 с.

Пешковский А. М., 1923. Школьная и научная грамматика. Опыт применения научно-грамматических принципов к школьной практике. М. ; Петроград : Госиздат. 115 с.

Теньер Л., 1988. Основы структурного синтаксиса. М. : Прогресс. 656 с.

Шигуров В. В., 1993. Типология употребления атрибутивных форм русского глагола в условиях отрицания действия / науч. ред. Л. Л. Буланин. Саранск : Изд-во Мордов. ун-та. 385 с.

Шигуров В. В., 2007. Наречные слова-команды в контексте интеръективации и вербализации // Известия Российской академии наук. Серия литературы и языка. Т. 66, № 4. C. $23-34$

Шигуров В. В., 2009. Интеръективация как тип ступенчатой транспозиции языковых единиц в системе частей речи : (Материалы к транспозиционной грамматике русского языка). М. : Academia. 464 c.

Шигуров В. В., 2015. Прономинализация как тип ступенчатой транспозиции языковых единиц в системе частей речи : Теория транспозиционной грамматики русского языка. 2-е изд., испр. и доп. М. : Инфра-М. 160 с. (Серия: Научная мысль).

Шигуров В. В., 2016. Предикативация как тип ступенчатой транспозиции языковых единиц в системе частей речи : Теория транспозиционной грамматики русского языка. М. : Наука. 702 с.

Шигуров В. В., Шигурова Т. А., 2019. Исследование градуальной природы транспозиции русских глаголов в модальные показатели персуазивности // Образовательно-инновационные технологии: теория и практика / под общ. ред. проф. В. А. Далингера, проф. В. В. Шигурова ; отв. ред.: проф. О. И. Кириков, проф. В. И. Писаренко. Воронеж : ВГПУ ; М. : Наука : Информ. Кн. 31. С. 43-54.

Marchand H., 1967. Expansion, Transposition and Derivation // La Linguistigue. № 1. P. 13-26.

\section{ИСТОЧНИК}

Национальный корпус русского языка. URL: http:/ /www.ruscorpora.ru. 


\section{REFERENCES}

Babaytseva V.V., 2000. Yavleniya perekhodnosti $v$ grammatike russkogo yazyka [The Phenomena of Transitivity in the Grammar of the Russian Language]. Moscow, Drofa Publ. 640 p.

Balli Sh., 1955. Obshchaya lingvistika $i$ voprosy frantsuzskogo yazyka [General Linguistics and Issues of the French Language]. Moscow, Izd-vo inostrannoy literatury. $416 \mathrm{p}$.

Bauder A.Ya., 1982. Chasti rechi - strukturnosemanticheskie klassy slov $v$ sovremennom russkom yazyke [Parts of Speech as StructuralSemantic Classes of Words in Modern Russian]. Tallinn, Valgus Publ. 184 p.

Vorotnikov Yu.L., 2003. Slovo i vremya [Word and Time]. Moscow, Nauka Publ. 167 p.

Vysotskaya I.V., 2006. Sinkretizm v sisteme chastey rechi sovremennogo russkogo yazyka [Syncretism in the System of Parts of Speech of the Modern Russian Language]. Moscow, Izd-vo MPGU. 304 p.

Kalechits E.P., 1990. Vzaimodeystvie slov v sisteme chastey rechi: mezhkategorialnye svyazi [Interaction of Words in the System of Parts of Speech: (Cross-Category Communication)]. Sverdlovsk, Izd-vo Uralskogo universiteta. 160 p.

Kim O.M., 1978. Transpozitsiya na urovne chastey rechi $i$ yavlenie omonimii v sovremennom russkom yazyke [Transposition at the Level of Parts of Speech and the Phenomenon of Homonymy in Modern Russian]. Tashkent, Fan Publ. 228 p.

Kubryakova E.S., 1981. Tipy yazykovykh znacheniy. Semantika proizvodnogo slova [Types of Linguistic Meaning. Semantics of the Derived Word]. Moscow, Nauka Publ. 200 p.

Kurilovich E., 2000. Ocherki po lingvistike [Essays on Linguistics]. Birobidzhan, TRIVIUM Publ. 50 p.

Migirin V.N., 1971. Ocherki po teorii protsessov perekhodnosti [Essays on the Theory of Transitivity Processes]. Balti. 199 p.

Peshkovskiy A.M., 1923. Shkolnaya i nauchnaya grammatika. Opyt primeneniya nauchnogrammaticheskikh printsipov $k$ shkolnoy praktike [School and Scientific Grammar. Experience of Applying Grammar Principles to School Practice]. Moscow, Petrograd, Gosizdat. 115 p.

Tener L., 1988. Osnovy strukturnogo sintaksisa [Fundamentals of Structural Syntax]. Moscow, Progress Publ. $656 \mathrm{p}$.

Shigurov V.V., 1993. Tipologiya upotrebleniya atributivnykh form russkogo glagola $v$ usloviyakh otritsaniya deystviya [Typology of the Use of the Attribute Forms of the Russian Verb in the Conditions of Denial of Action]. Saransk, Izd-vo Mordovskogo universiteta. 385 p.
Shigurov V.V., 2007. Narechnye slova-komandy v kontekste interyektivatsii i verbalizatsii [Adverb Commands in the Context of Interjectionalization and Verbalization]. Izvestiya Rossiyskoy akademii nauk. Seriya literatury $i$ yazyka [Bulletin of the Russian Academy of Sciences: Studies in Language and Literature], vol. 66, no. 4 , pp. $23-34$

Shigurov V.V., 2009. Interyektivatsiya kak tip stupenchatoy transpozitsii yazykovykh edinits $v$ sisteme chastey rechi: (Materialy $k$ transpozitsionnoy grammatike russkogo yazyka) [Interjectivation as a Type of Stepwise Transposition of Linguistic Units in the System of Parts of Speech. Materials for the Transpositional Grammar of the Russian Language]. Moscow, Academiya Publ. 464 p.

Shigurov V.V., 2015. Pronominalizatsiya kak tip stupenchatoy transpozitsii yazykovykh edinits $v$ sisteme chastey rechi: Teoriya transpozitsionnoy grammatiki russkogo yazyka [Pronominalization as a Type of Stepwise Transposition of Linguistic Units in the System of Parts of Speech. The Theory of the Transpositional Grammar of the Russian Language]. Moscow, Infra-M Publ. 160 p. (Seriya: Nauchnaya mysl [Series: Scientific Thought]).

Shigurov V.V., 2016. Predikativatsiya kak tip stupenchatoy transpozitsii yazykovykh edinits $v$ sisteme chastey rechi: Teoriya transpozitsionnoy grammatiki russkogo yazyka [Predicativeness as a Type of Stepwise Transposition of Linguistic Units in the System of Parts of Speech. The Theory of the Transpositional Grammar of the Russian Language]. Moscow, Nauka Publ. $702 \mathrm{p}$.

Shigurov V.V., Shigurova T.A., 2019. Issledovanie gradualnoy prirody transpozitsii russkikh glagolov v modalnye pokazateli persuazivnosti [Study of the Gradual Nature of the Transposition of Russian Verbs into Modal Indicators of Persuasivity]. Dalinger V.A., Shigurov V.V., Kirikov O.I., Pisarenko V.I., eds. Obrazovatelno-innovatsionnye tekhnologii: teoriya i praktika [Educational and Innovative Technologies: Theory and Practice]. Voronezh, VGPU, Moscow, Nauka Publ., Inform Publ., book 31, pp. 43-54.

Marchand H., 1967. Expansion, Transposition and Derivation. La Linguistigue, no. 1, pp. 13-26.

\section{SOURCE}

Natsionalnyy korpus russkogo yazyka [Russian National Corpus]. URL: http://www.ruscorpora.ru/. 


\section{РАЗВИТИЕ И ФУНКЦИОНИРОВАНИЕ РУССКОГО ЯЗЫКА}

\section{Information About the Author}

Victor V. Shigurov, Doctor of Sciences (Philology), Professor, Head of the Russian Language Department, National Research Ogarev Mordovia State University, Bolshevistskaya St., 68, 430005 Saransk, Russia, dep-general@adm.mrsu.ru, shigurov@mail.ru, https://orcid.org/0000-0002-4898-6484

\section{Информация об авторе}

Виктор Васильевич Шигуров, доктор филологических наук, профессор, заведующий кафедрой русского языка, Национальный исследовательский Мордовский государственный университет им. Н.П. Огарева, ул. Большевистская, 68, 430005 г. Саранск, Россия, dep-general@adm.mrsu.ru, shigurov@mail.ru, https://orcid.org/0000-0002-4898-6484 